PACS: $61.80 . \mathrm{Ba}$

\title{
THE FORMATION OF SURFACE LAYERS IN Zr-Fe ALLOYS UNDER ION IRRADIATION
}

\author{
V.G. Kirichenko, V.A. Kobylnik, T.A. Kovalenko, O.A. Usatova \\ V. N. Karazin Kharkiv National University \\ 4. Svobody Sq., 61022, Kharkiv, Ukraine \\ E-mail: val.kir.248@gmail.com \\ Received April 25, 2017
}

The study of phase transformations in intermetallic phases, which are released in the form of fine-dispersed inclusions in binary alloys based on zirconium $\mathrm{Zr}-1.03$ at. \% Fe; $\mathrm{Zr}-0.51$ at. \% Fe; after ion irradiation and subsequent isothermal annealing was carried out. Mössbauer spectroscopy on ${ }^{57} \mathrm{Fe}$ nuclei in backscattering geometry with registration of internal conversion electrons, X-ray spectral analysis, X-ray diffraction analysis and electron microscopy were used. As a result, the observed segregation and phase composition of the intermetallic phases in the surface layer change under ion irradiation. Subsequent isothermal annealing after irradiation leads to a change in the concentration of inclusions of intermetallic phases and phase modification in the surface layer.

KEY WORDS: zirconium, alloys, phases, segregation, ion, irradiation

\section{ФОРМУВАННЯ ПОВЕРХНЕВИХ ШАРІВ В Zr-Fе СПЛАВАХ ПРИ ІОННОМУ ОПРОМІНЮВАННІ \\ В.Г. Кіріченко, В.А. Кобильник, Т.О. Коваленко, О.О. Усатова \\ Харківський національний університет імені В.Н. Каразіна \\ 61022, Харків, м. Свободи, 4}

У роботі проведено дослідження фазових перетворень в інтерметалічних фазах, які виділяються у вигляді дрібнодисперсних включень в бінарних сплавах на основі цирконію після іонного опромінення і подальшого ізотермічного відпалу. Використовували мессбауерівську спектроскопію на ядрах ${ }^{57} \mathrm{Fe}$ в геометрії зворотного розсіювання 3 реєстрацією електронів внутрішньої конверсії, рентгеноспектральний аналіз, рентгеноструктурний аналіз і електронну мікроскопію. В результаті виявлена сегрегація і фазовий склад интерметаллических фаз в поверхневому шарі змінюється при іонному опроміненні. Подальший ізотермічний відпал після опромінення призводить до зміни концентрації включень интерметаллических фаз і модифікації фаз в поверхневому шарі.

КЛЮЧОВІ СЛОВА: цирконій, сплави, фази, зріст, сегрегація, іон, опромінення

\section{ФОРМИРОВАНИЕ ПОВЕРХНОСТНЫХ СЛОЕВ В Zr-Fе СПЛАВАХ ПРИ ИОННОМ ОБЛУЧЕНИИ \\ В.Г. Кириченко, В.А. Кобыльник, Т.А. Коваленко, О.А. Усатова \\ Харьковский национальный университет имени В.Н. Каразина} 61022, г. Харьков, пл. Свободы, 4

В работе проведено исследование фазовых превращений в интерметаллических фазах, которые выделяются в виде мелкодисперсных включений в бинарных сплавах на основе циркония после ионного облучения и последующего изотермического отжига. Использовали мессбауэровскую спектроскопию на ядрах ${ }^{57} \mathrm{Fe}$ в геометрии обратного рассеяния с регистрацией электронов внутренней конверсии, рентгеноспектральный анализ, рентгеноструктурный анализ и электронную микроскопию. В результате обнаруженная сегрегация и фазовый состав интерметаллических фаз в поверхностном слое изменяется при ионном облучении. Последующий изотермический отжиг после облучения приводит к изменению концентрации включений интерметаллических фаз и модификации фаз в поверхностном слое.

КЛЮЧЕВЫЕ СЛОВА: цирконий, сплавы, сегрегация, ион, облучение

Zirconium alloys such as E-110M, E-125, E-635, Zry-2, Zry-4, M5, ZIRLO have been widely used in nuclear power engineering [1]. The basic problems in the operation of zirconium alloys under irradiation are due to the presence of radiation growth and radiation creep due to anisotropy of $\alpha$ - zirconium. Used zirconium alloys differ with radiation growth, radiation creep, corrosion resistance, high temperature strength [2]. The experimental results on the formation of gradient corrosion-resistant structural-phase states in materials and fuel claddings of thermal reactors have been considered and summarized [3]. The action by high-temperature pulsed plasma flows is effective for changing the surface layer of materials. For example, as applied to E110 and E635 zirconium alloys, new structural-phase states formed by the method of "ion mixing" [3].

Such effects are associated with recently discovered gradient materials with high technological properties [4]. Optimization of gradient materials is realized by introducing nanoparticles into the surface layers. In [5] it is found that an increase in the surface concentration of iron atoms in zirconium alloys in a layer up to $0.3 \mu \mathrm{m}$ thick is associated with an increase in the size of inclusions with an increase in the annealing temperature of the deformed alloys. The amorphization alloys based on zirconium under ion irradiation was observed [6]. The formation of amorphous intermetallic phases on the surface of zirconium alloys after ion irradiation can be attributed to the viscosity of zircaloys and the influence of the viscosity of the metallic matrix on the crystallization of amorphous phases during annealing after irradiation [6]. 
The purpose of this work is the research after ion irradiation of surface layers of zirconium alloys with $\mathrm{Fe}^{57}$ additions by Mossbauer spectroscopy on $\mathrm{Fe}^{57}$ nuclei.

\section{EXPERIMENTAL METHODS}

For the study alloys $\mathrm{Zr}-1.03$ at. \% Fe, $\mathrm{Zr}-0.51$ at. \% Fe was made. The procedure for their preparation is described in [6]. Mössbauer spectroscopy on ${ }^{57} \mathrm{Fe}$ nuclei was used in the backscattering geometry with registration of internal conversion electrons (CEMS). An X-ray spectral analysis of the surface of annealed zirconium alloy samples was carried out on a Camebax MBX 268 spectrometer. X-ray study of alloys was carried out on the DRON-3.0. X-ray diffraction analysis showed that at all stages of thermo mechanical processing of alloys the matrix phase composition is represented by the alpha-phase of $\mathrm{Zr}$.

\section{RESULTS AND DISCUSSION}

The solubility limit of $\mathrm{Fe}$ in $\alpha-\mathrm{Zr}$ decreases from value $0.015 \pm 0.001 \%$ at $943 \mathrm{~K}$ to value $0.004 \pm 0.001 \%$ at $713 \mathrm{~K}$ [7,8]. Consequently, when doping zirconium with iron in the metallic matrix of alloys the precipitates of intermetallic phases of complex composition are formed. In a binary $\mathrm{Zr}-\mathrm{Fe}$ system 5 intermetallic compounds was found: $\mathrm{Zr}_{4} \mathrm{Fe}$, $\mathrm{Zr}_{3} \mathrm{Fe}, \mathrm{Zr}_{2} \mathrm{Fe}, \mathrm{ZrFe}_{2}$ and $\mathrm{ZrFe}_{3}$ [9].The equilibrium $\mathrm{Zr}$-Fe phase diagram is shown in Fig. 1 [10].

\section{Weight Percent lron}

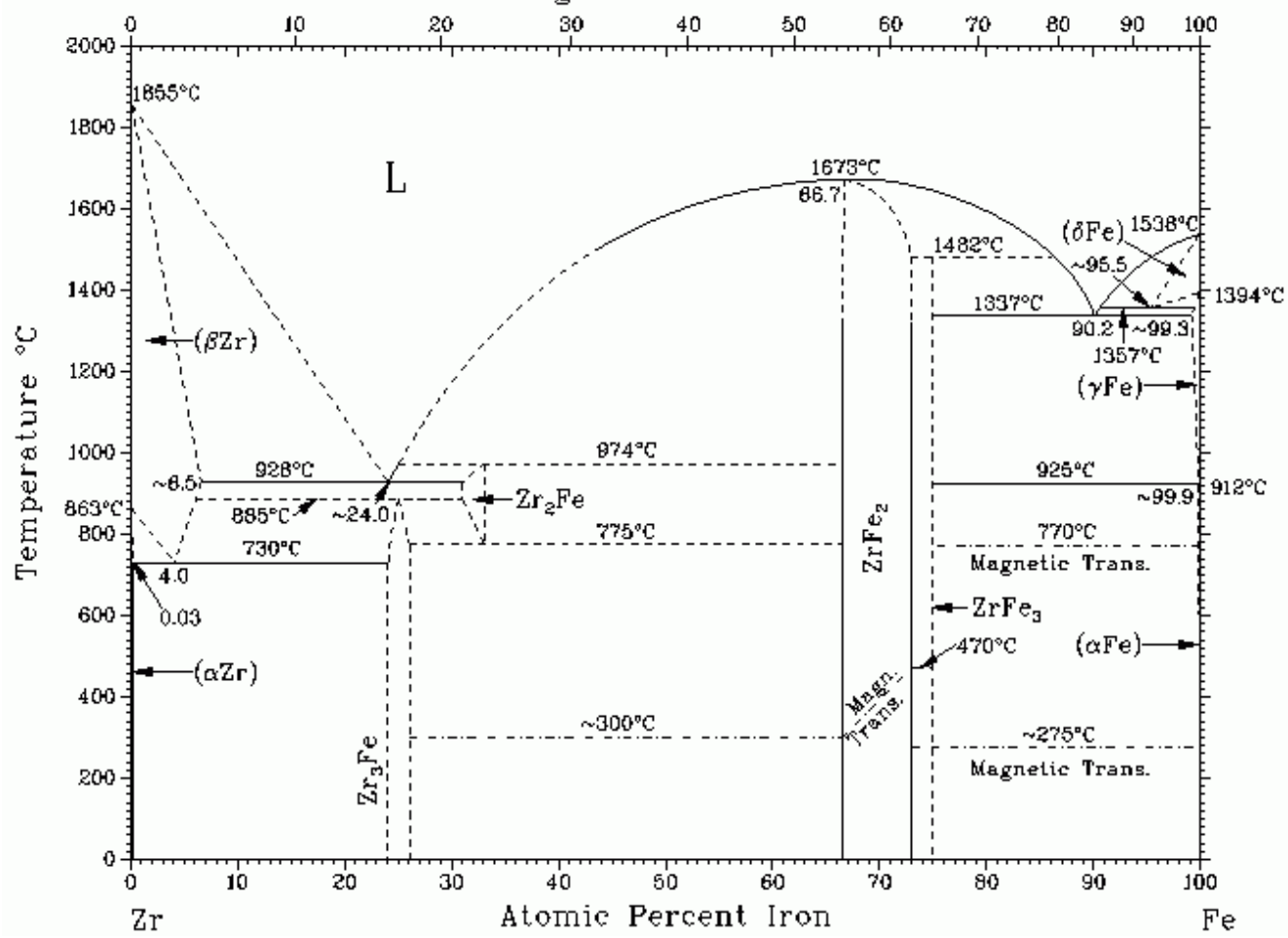

Fig. 1. The equilibrium $\mathrm{Zr}-\mathrm{Fe}$ phase diagram

Parameters of Mossbauer spectra of formed intermetallic phases in Zr-Fe system are given in the Table.

The Mossbauer parameters of the phases in the binary system Zr-Fe

\begin{tabular}{|c|c|c|c|c|}
\hline Phase & Isomer shift, $\delta, \mathrm{mm} / \mathrm{s}$ & $\begin{array}{l}\text { Quadruple splitting, } \\
\Delta, \mathrm{mm} / \mathrm{s}\end{array}$ & Composition, at. $\% \mathrm{Fe}$ & Crystal structure \\
\hline $\mathrm{ZrFe}_{2}$ & $-0.22(1)$ & $0.46(1)$ & 67 & C15 type \\
\hline $\mathrm{Zr}_{2} \mathrm{Fe}$ & $-0.31(1)$ & $0.75(1)$ & 33 & $\mathrm{CuAl}_{2}$ type \\
\hline $\mathrm{Zr}_{2} \mathrm{Fe}$ & $-0.12(1)$ & $0.30(1)$ & 33 & $\mathrm{Ti}_{2} \mathrm{Ni}$ type \\
\hline $\mathrm{Zr}_{3} \mathrm{Fe}$ & $-0.33(1)$ & $0.91(1)$ & 25 & $\mathrm{Re}_{3} \mathrm{~B}$ type \\
\hline$\alpha-\mathrm{Zr}_{4} \mathrm{Fe}$ & $-0.34(1)$ & $0.85(1)$ & 20 & hexagonal structure \\
\hline$\beta-\mathrm{Zr}_{4} \mathrm{Fe}$ & $-0.3(1)$ & $0.75(1)$ & 20 & orthorhombic structure \\
\hline$\underline{\mathrm{ZrFe}}$ (solid solution) & $0.04(1)$ & - & 0.02 & $\alpha$-phase \\
\hline
\end{tabular}

CEMS scattering spectrum of the surface of the $\mathrm{Zr}-1.03$ ат \% Fe alloy after annealing at $970 \mathrm{~K}$ for $5 \mathrm{~h}$ is shown on Fig. 2. The spectrum has a doublet structure with doublet parameters characteristic for the phase $\mathrm{Zr}_{3} \mathrm{Fe}$. 
According to experimental data the stable phase $\mathrm{Zr}_{3} \mathrm{Fe}$ is formed after high temperature annealing (1100-1200 K) and has the orthorhombic $\mathrm{Re}_{3} \mathrm{~B}$ type structure with $a=3.326 \AA, b=10.988 \AA, c=8.807 \AA$. Fe atoms in this structure have only one position and with $6 \mathrm{Zr}$ atoms as nearest neighbors [9].

Deformed alloys characterized broadened X-ray reflexes due to the increase in the dislocation density in the surface layer, furthermore, the formation of segregations of a second phase on the formed defects.

Analysis of the scattering spectra of annealed deformed alloys in the $\mathrm{Zr}-\mathrm{Fe}$ system leads to the conclusion that the surface layer is enriched with intermetallic inclusions, which contain in its composition Fe atoms.

The degree of enrichment of the surface layer due to the creation of a gradient layer as a result of thermal annealing of deformed alloy is shown in Fig. 3. Experimental data are presented as the diagram in the coordinates C-T to describe the surface segregation of intermetallic phases inclusions, where $\mathrm{C}$ - concentration ${ }^{57} \mathrm{Fe}$ atoms composed of intermetallic phase; $\mathrm{T}-$ the annealing temperature (Fig. 3). The concentration of ${ }^{57} \mathrm{Fe}$ atoms increase with temperature of annealing emphasizing the greatest increase in iron concentration and consequently the presence of gradient of intermetallic phases in the surface layer.

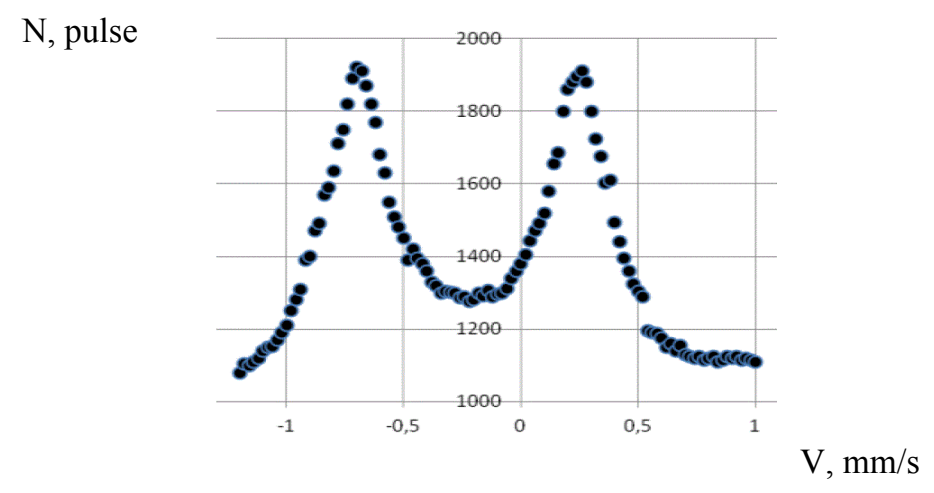

Fig. 2. CEMS scattering spectrum of the surface of the $\mathrm{Zr}-1,03$ ат\% $\mathrm{Fe}$ alloy after annealing at $970 \mathrm{~K}$ for $5 \mathrm{~h}$
C, at. $\%$

12

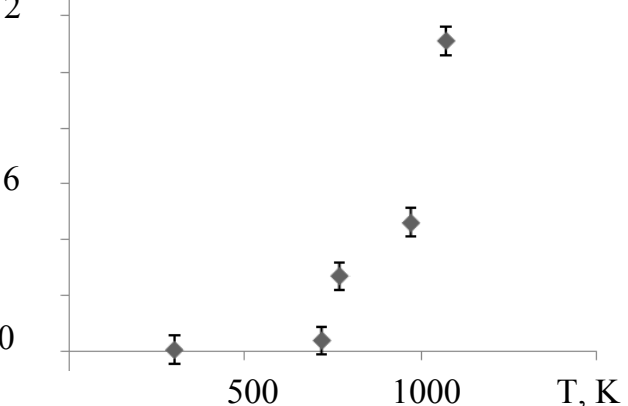

Fig. 3'. Dependence of iron concentrations in the surface layer Depth $300 \mathrm{~nm}$ of the alloy from the thermal annealing temperature of the deformed layer $\mathrm{Zr}-1.03$ at. $\% \mathrm{Fe}$

The results of calculations using the program SRIM-2008.04 of damages cascade and ion profile of the distribution of iron atoms in the $\mathrm{Zr}-1.03$ at. \% alloy under irradiated with iron ions with an energy of $600 \mathrm{keV}$ are shown in Fig. 4,5.

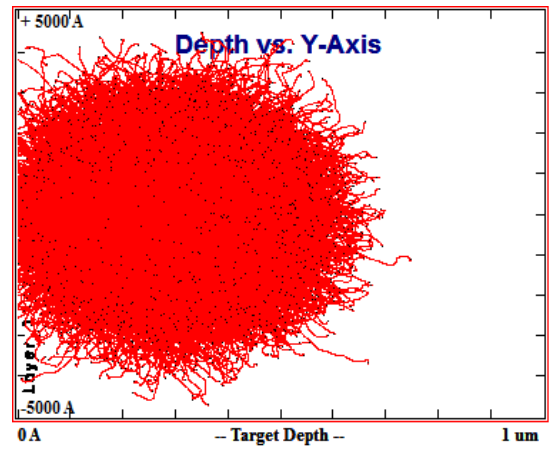

Fig. 4. Damage cascade with energy of $600 \mathrm{keV}$ ions

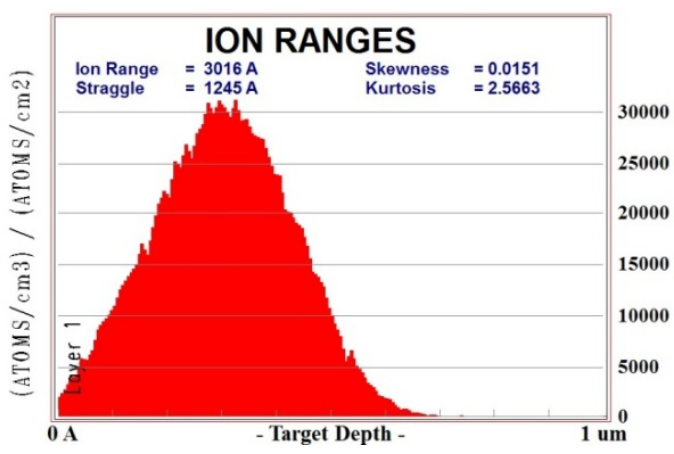

Fig. 5. Ion distribution under energy of $600 \mathrm{keV}$ ions

The results of the calculations indicate that there is a weak dependence of the diameter of the cascade band $d$ and the energy ranges $\mathrm{R}$ on the alloy composition and the strong dependence on the ion energy.

The calculations carried out with the help of the SRIM-2008.04 program will make it possible to make an effective choice of ion irradiation regimes in imitation experiments. The results of calculations of the effect of ion irradiation of a layer of zirconium-iron alloy which contain $12 \mathrm{at} \%$ iron in a layer $300 \mathrm{~nm}$ and $600 \mathrm{~nm}$ deep, respectively, are shown in Fig. 6,7.

CEMS spectrum of $\mathrm{Zr}-1.03$ at\% Fe alloy surface layer, which enriched up to 12 at. \% Fe, after iron ion irradiation with an energy of $600 \mathrm{keV}$ and after addition annealing at $970 \mathrm{~K}$ for $5 \mathrm{~h}$ is shown in Fig. 8. This spectrum consists of two components belonging to the amorphous phase (with a smaller value of quadruple splitting), which was formed after irradiation and the crystalline phase into which the amorphous phase turns during annealing. The spectrum of the crystalline phase has a higher value of quadruple splitting.

The dependence of the concentration change $\Delta C$ in the $300 \mathrm{~nm}$ layer on the iron content $\mathrm{C}$ in the layer and the additional annealing temperature $\mathrm{T}$ after irradiation is shows In Fig. 9. This 3D -diagram demonstrate the dependence 
of the iron content on the annealing temperature in the surface layer $300 \mathrm{~nm}$ deep after ion irradiation and after additive annealing. This data demonstrate the possibility of the controlled formation of gradient layers after thermal annealing and ion irradiation. Additional annealing reduces the spatial scale of the created gradient structures in the concentration range of $14-16 \%$ and the annealing temperature range of $670-720 \mathrm{~K}$.

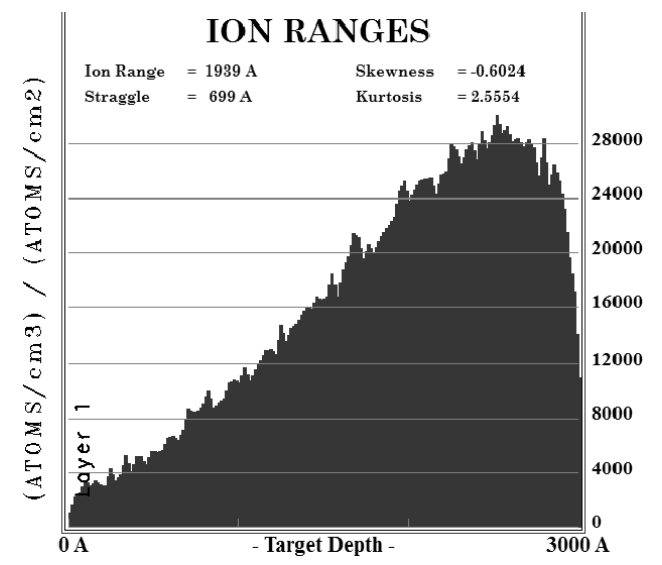

Fig. 6. Distribution of iron ions in the zirconium-iron alloy layer with a layer depth of $300 \mathrm{~nm}$

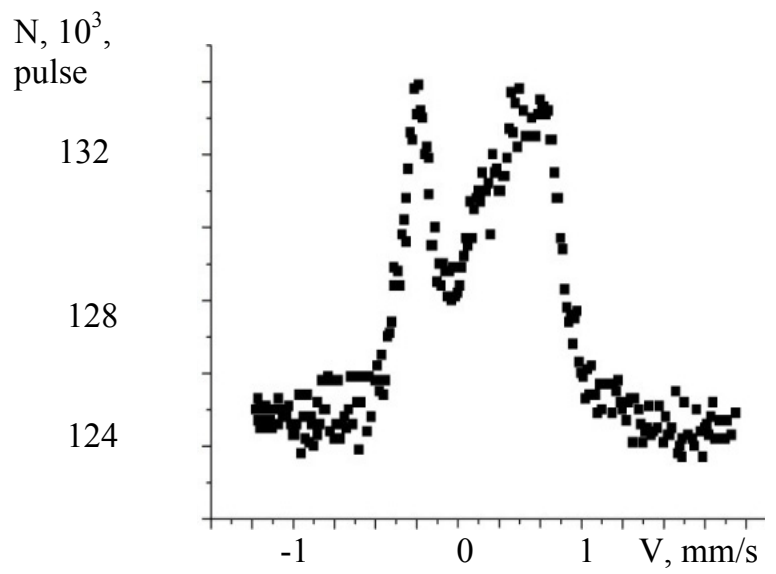

Fig. 8. CEMS spectrum of surface of Zr-1.03 at $\% \mathrm{Fe}$ alloy after iron ion irradiation with an energy of $600 \mathrm{keV}$ and after annealing at $970 \mathrm{~K}$ for $5 \mathrm{~h}$

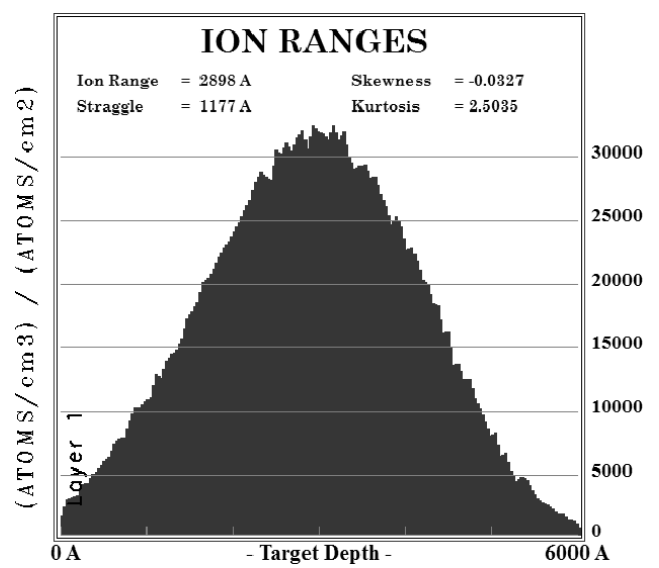

Fig. 7. Distribution of iron ions in the zirconium-iron alloy layer with a layer depth of $600 \mathrm{~nm}$

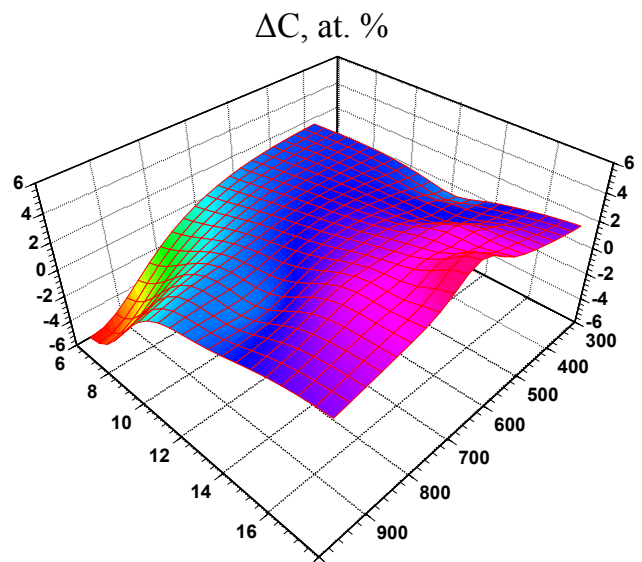

C, at. $\%$

$\mathrm{T}, \mathrm{K}$

Fig. 9. The dependence of the concentration change in the 300 $\mathrm{nm}$ layer on the iron content in the layer and the additional annealing temperature after irradiationture

Another important problem is the amorphization of intermetallic phases in surface layer under the irradiation by ions of the amorphous state of alloys, metastable and crystalline phases are formed after further annealing, while the crystallization temperatures and the entropy of crystallization activation depend on the composition of the alloy.

\section{CONCLUSIONS}

Thus, a layer of $300 \mathrm{~nm}$ depth enriched with intermetallic inclusions before irradiation of the surface of the zirconium-iron alloy was created by thermal annealing of the deformed alloys. Irradiation by $\mathrm{Fe}^{4+}$ ions with energy 600 $\mathrm{keV}$ of surface enriched layer leads to transformation of crystalline $\mathrm{Zr}_{3} \mathrm{Fe}$ to amorphous phase. It is possible to create multi component gradient structures under ion irradiation of the alloy surface. The growth and disintegration of inclusions under thermal annealing after irradiation is not controlled by bulk diffusion and the migration of iron atoms can be associated with the presence of inter phase boundaries was found

\section{REFERENCES}

1. Solonin M.I., Reshetnikov F.G., Nikulina V.A. New Construction Materials for Active Zone in Nuclear Power Plants // Nucl. Mater. - 2004. - Vol. 25. - P.12-14.

2. Rogerson A. Irradiation growth in zirconium and its alloys // J. Nucl. Mater. - 1988. - Vol.159. - P.43-61.

3. Kalin B.A., Volkov N.V., Yakushin V.L. Radiation-beam action as a method to form gradient structural-phase state in materials of nuclear engineering // Problems of Atomic Science and Technology. Series: Physics of Radiation Damage and Radiation Material Science. - 2007. - No.2 (90). - P.164-171. 
4. Na K.S., Kim J.H. Optimization of volume fractions for functionally graded panels considering stress and critical temperature // Composite structures. - 2009. - Vol.89. - P. 509-516.

5. Kirichenko V.G., Yampolsky A.A. Features of the formation of surface gradient layers in zirconium alloys // Problems of Atomic Science and Technology. Series: Physics of Radiation Damage and Radiation Material Science. - 2017. - No. 2 (108). P. 114-116.

6. Kirichenko V.G., Azarenkov N.A. Nuclear physics of zirconium alloys. - Kharkiv: KHNU imeni V.N. Karazina, 2012. - 336p. (In Russian)

7. Stupel M.M., Weiss B.Z. Determination of Fe solubility in $\alpha$-Zr by Mossbauer spectroscopy // Scr. Met. - 1985. - Vol. 19. No. 6. - P. 739-740.

8. Filippov V.P., Kirichenko V.G., Salomasov V.A., Khasanov A.M. Phase transformations in intermetallic phases in zirconium alloys // Hyperfine Interact. (2017) 238:23. - DOI 10.1007/s10751-016-1377-3. Springer International Publishing Switzerland 2017.

9. Aubertin F., Gonser U., Campbell S. An appraisal of the phases of the Zirconium-Iron system // Z. Metallkunde. - 1985. - Bd. 76. - No. 4. - S. 237-244.

10. http://www.himikatus.ru/art/phase-diagr1/Fe-Zr.php 